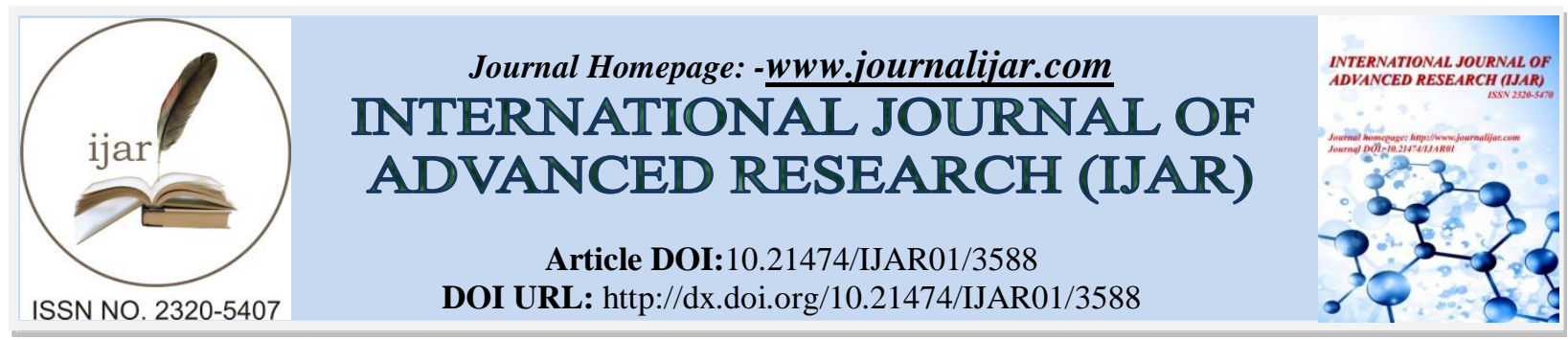

RESEARCH ARTICLE

\title{
THE RELATIONSHIP BETWEEN LEARNING PROCESS IN PESANTREN AND ENERGY CONSERVATION LAW (STUDY OF THE INTERNALIZATION OF RELIGION VALUES RELATED WITH LIFE ENVIRONMENT).
}

\section{Udji Asiyah $^{1}$, Zaenal Fanani ${ }^{2}$ and Ratna Azis Parsetyo ${ }^{1}$.}

1. Department of Sociology, Faculty of Social and Political Sciences, University of Airlangga.

2. Professor in Postgraduate Program, University of Brawijaya Malang.

\section{Manuscript Info}

Manuscript History

Received: 04 January 2017

Final Accepted: 10 February 2017

Published: March 2017

Key words:-

Pesantren, life environment, learning, energy conservation law, punishment.

\begin{abstract}
Research attempts to review the understandings and concepts of life environment learned in Moslem Boarding House (Pesantren), to examine how is the learning of religion values related with life environment, and to acknowledge how this learning is implemented. This research was located at Pesantren Al Kahfi Sidoarjo, and exploration was done through several ways. First, primary data are collected from respondents of santri (students in Pesantren), either boys and girls. Second, in-depth interview is conducted with the managing boards of Pesantren. The findings of research were described as following: (1) The learning is given to produce a change in students on the directions made by Pesantren. This change concerns with environmental issue, meaning that the understanding of students about environmental issue would change. Most students (90.2\%) have understood life environment concept and agreed if the review of life environment must be delivered every day or every week. Others (98.7\%) have agreed with proverb that cleanliness is a part of the faith. (2) Few students reject such life environment concepts and its reviews. The reason behind this reject is that there is still a strong patriarchy culture which frames the way the students think. The condition where students live still influences their behavior. (3) The learning is emphasized on the importance of environmental cleanliness. It is done by reciting books about this issue, by organizing the outing class or the contests of making poster with contents of environmental cleanliness and learning comfort, and by conducting homage service around Pesantren. (4) Some students (78.1\%) agree that homage service could be held once a week, and some others (75.6\%) declare that punishment should be given for the negligent. (5) Any violation to the agreement (homage service) will be subjected to fine or other kind of punishment.
\end{abstract}

Copy Right, IJAR, 2017,. All rights reserved.

\section{Introduction:-}

Pesantren is an organization of preaching or education. It has some functions. First, Pesantren prepares Moslem youths with education in order to produce Islamic generation with good moral quality (khaira ummah), with an understanding on mission of amar ma'ruf nahi munkar and also with a sense of kindness. Second, Pesantren is also a 
place to educate the cadres of Moslem scholars, the agent of excellence, and the developer of science, especially theology. It can be said that the tasks of Pesantren are to prepare and educate thâ ifah mutafaqqihah fid-dîn, respectively the cadres of Moslem scholars and the caretaker of Pesantren who always respect personality of Prophet Mohammed and have a willingness to implement the duty of indzârul qawm (Abdurrahman, 2008).

A certain effort may determine the force that moves a certain thing. But, this effort does not influence the length of time when the force subjects to a thing to move. Sometimes, the effort is fast, or even slow at other times. For instance, Siti push the cupboard to move it to the other corner at distance of $3 \mathrm{~m}$. Siti needs 5 minutes to move the cupboard there. Budi can move the same cupboard only by 3 minutes. Siti and Budi do same effort, but time needed for each effort is different. The effort per unit of time is called energy. It is then said that Budi has bigger energy than Siti. Energy is defined as the rate of effort in unit of time. Energy represens a capacity to use the effort. Energy is indestructible but it only changes its shape.

\section{Method of Research:-}

Research uses a mixed method comprising of quantitative and qualitative measures. Both are used simultaneously in a way suggested by Creswell (2012), and it is called as concurrent mixed methods.

Quantitative method is represented by survey, whereas qualitative method involves case study. Survey is used to collect quantitative data, especially those concerning with undertandings of life environment in Pesantren and the effect the life environment may have on the learning in Pesantren. Case study is useful to collect data on the description of "unique cases" related with learning process.

The object of research is Pondok Pesantren Dakwah Al Kahfi, Tarik-Sidoarjo. This Pesantren also opens formal school, called Integated Islam Junior High School. It tries to prepare Moslem youths with Islamic personalities, knowledge of Islam religion, Arab language, knowledge of preaching, and general knowledge.

To enrich information about these unique cases in learning process, then in-depth interview is conducted with some selected informants, which in this case, involving teachers and religious elders or Kyai. Questionnaire is given randomly to Pesantren students.

All data are subjected to analysis. First, the analysis of quantitative data involves arranging the data into frequency table to describe the reality observed. Second, qualitative data are analyzed by displaying data into narrative textual explanations to describe the reality observed.

\section{Result and Discussion:-}

The Learning Process in Pesantren Al Kahfi:-

Religion values represent the guidance to produce good, fair and proper behavioral standard. These values are derived from religious norms. These norms usually bind the believers into several rules or prohibitions. Believers must obey the rules to obtain happiness in the world and the hereafter. Violating these rules will lead to the act of $\sin$.

Educational environment in Pesantren is very suitable to be a secondary learning medium to create good personality. Formal education does not match with this personality goal. It is also incompatible for personality building because teaching at formal school is not wisely given and teaching style is too much monotonous. Learning structure and infrastructure are not feasible to develop good personality in students.

The list of incompatibility factors still grows. Students may be assigned into less proper learning groups. Improper learning habit, poor learning achievement, bad learning behavior among friends, and too strict school regulation, are only factors causing difficulty, anxiety, disappointment and dissatisfaction among students. Healthy and convenient school environment is therefore needed. Education at school is a secondary learning place, and it is where formal learning is done. At school, children not only learn how to read, write and count, but also understand the importance of self-dependence, achievement, universalism, and specificity.

Learning Process of Religion Values. Learning the religion values related with life environment in Pesantren Al Kahfi is an action directly done by students with their consciences. Students are aware with the importance of 
working together with friends and of making interaction with other individuals in Pesantren. Rules in Pesantren must be understood to keep students to realize that certain norms and values have prevailed in Pesantren.

After accepting these rules, students are considered as able to take a certain position into the community. In other words, students indeed have a capacity of tolerance and interaction not only with others at same age, but also with the community.

Curriculum To Support Religion Values. Learning environment in Pesantren Al Kahfi is a classroom type but religion values and character education are set into learning materials. Religion material (diniyah) is also given and it is supported by reviewing some religion books, such as (1) Book of Bulughul Maram (containing rules of devotion and rules of behavior); (2) Book of Taklim Muta'alim (explaining politeness and morality); (3) Book of Fiqh Sayid Tsabit (concerning with rules of devotion, issues of holiness and cleanliness, others); (4) Book of Siroh Nabawiyah (history of Prophet Mohammed and his struggle on Islam mission); and (5) Conflict Management.

Change Process in Pesantren. Social change has many definitions. According to Ranjabar (2001;17), social change is a process where structural change of the community goes along with the change of the culture and function of a social system. In the words of Gillin and Gillin (in Poloma, 1979), social change is a variation of life styles that are accepted as good because it is compatible with the change of geographical condition, material culture, geographical composition, or ideology. The change may be desired because it is diffused fast or there is new inventions in the community. In short, Samuel Koenig $(1957 ; 279)$ said that social change refers to modifications occuring in the living pattern of the human. These modifications occur with internal and external causes.

Students as one stakeholder in Pesantren are subjected to the rules prevailed in Pesantren. These rules will organize their activity in 24 hours a day from wake-up in the morning to the sleep at night. Learning-teaching activity is also conducted on these rules.

Pesantren is unique if compared to other educational institutions. Students or santri in Pesantren are living together with their teacher or kyai in one certain complex of self-dependence settlement. The following is general characteristics of Pesantren.

a. There is intimate relationship between santri and kyai.

b. Santri is always obedient and submissive to kyai.

c. Santri lives at simple and self-dependent ways.

d. There is mutual-share with sense of kinship.

e. Santri is trained with discipline and asceticism.

In the history of Indonesia, Pesantren plays significant role in enforcing faith, improving piety, fostering morality, developing self-dependence, and enlightening the nation through informal, non-formal and also formal educations provided by Pesantren. Being informal institution, Pesantren acts as a big family that helps enshaping the personality of santri. Pesantren also teaches skills that may help santri to develop their self-dependent capacity.

Energy and Effort. Energy plays very important role for the living of human and also for the progress of a nation. All human activities are done with energy. From pre-history to history periods, woods are the only source of energy for cooking and heating. In early part of thirteenth century, the coal was introduced. Steam engine was invented and using coal as its energy source until at eighteenth century, when new development came to the human life. Steam engine could produce quite enormous energies to mobilize industrial machines. It shot the fire of industrial revolution in Eropean countries where energy was used in huge quantity.

In the early of nineteenth cenutry, the emergence of fossil-oil as energy source has replaced coal as the source of heating and lighting. This oil is then displaced by electric in the end of nineteenth century. Electricity is produced from the rotating components in generator. However, energy source used to activate generator is coming from fossiloil, coal, and natural gas. Electrical energy plays important role in human living. In twentieth century, some alternatives of energy are ready to be used by human, including native heat, nuclear, and solar energies.

Energy Conservation Law concerns with the change of energy. Some energies are considered, such as radiation energy, potential energy, and chemical energy. Radiation means as disseminating toward the affordable spots. Radiation energy can be found in the beams of the sun that subject directly to the earth, or the sense of warm from 
the bonfire. Potential energy is an energy that moves to produce other energy. The silent propeller does not produce energy, but when the propeller moves with the wind, it creates electricity. Therefore, the propeller has changed its potential energy into kinetic energy, and finally, producing electric energy.

It is said that energy is a capacity needed for doing an effort. Someone may need energy to walk, run, work, and do other activities. Foods and beverages provide chemical energy to be burnt in human body, and this energy is used for many efforts or activities. Someone is said as doing an effort when pushing a certain thing. The rate of effort depends on the force used to push the thing and the distance of displacement of this thing.

The definition of effort in physic involves two requirements. First, the force subjected to a thing must move the thing to displace at certain distance. Second, to ensure that a force does an effort on the thing, then the force must have a direction in parallel with the direction of displacement. Effort in daily life is activity done by human. For instance, kyai tries to improve the progress of Pesantren with various strengths and strategies. Teachers apply learning method on students' needs. Santri learns physic for preparing daily exam and others.

\section{The Relationship Between Learning Process and Energy Conservation Law:-}

Pesantren Al Kahfi is full-day school at the level of Junior High School. Learning schedule ends in ashar (15.00 $\mathrm{pm})$. Teachers control the process in shifts. In Teacher Office, male and female teachers are separated for convenience. This separation is aimed to reduce unnecessary talk and interaction, and the interaction ends in ashar. The exception of separation is only made during the meeting.

Learning activity begins from 03.15 am in early morning. Santri is waken up and prepared for sholat yaumul lail (night prayer), and after that, it continues with waiting the time for sholat Subuh. After sholat shubuh, santri recites the Pray of Al-Ma'tsurat and follows it with dzikir. Recitation of Al Qur'an is done until $6.30 \mathrm{am}$. When this ends, santri takes shower and does a breakfast. At 7.20 am sharp, school begins with diniyah (religion) and other materials relevant in Junior High School.

Pesantren integrates three materials into one learning package. These materials are: school internal (curriculum from National Education), diniyah (religion, related with interpretation and riyadus sholihin) and Al-Quran recitation expertise. It becames the distinctive marker of Pesantren Al Kahfi that distinguishes it from other Integrated Islamic School. Students at other schools may memorize 2 juz or 3 juz of Al-Quran. In Pesantren Al Kahfi, students at Second Grade have memorized 30 juz of Al-Quran, and one of them is Rani.

The integration of learning materials is communicated early to parent or student guardian. At Pesantren Al Kahfi, $100 \%$ items in the National Education Curriculum are implemented, but it is added with Religion and AL-Quran Recitation. It may answer the question of parent about what kind of school is provided by Pesantren. During the preparation of national exam, the materials of exam are drilled to expect students for obtaining high academic achievement.

The internalization of religion values related with life environment is conducted during learning process at school or Pesantren. These religion values are delivered by reciting religion books, by organizing the outing class or the contests of making poster with contents of environmental cleanliness and learning comfort, and by conducting homage service around Pesantren. Some students suggest punishment for the negligent, such as buying cleaning tools or cleaning two rest rooms in two days in a row. Santri also expects that teachers must intensify the message that damanging the environment is a sin.

If related to energy conservation law, learning at Pesantren Al Kahfi has brought a change consistent with the plan of Pesantren. The fact that learning process has given good change is described as following: 


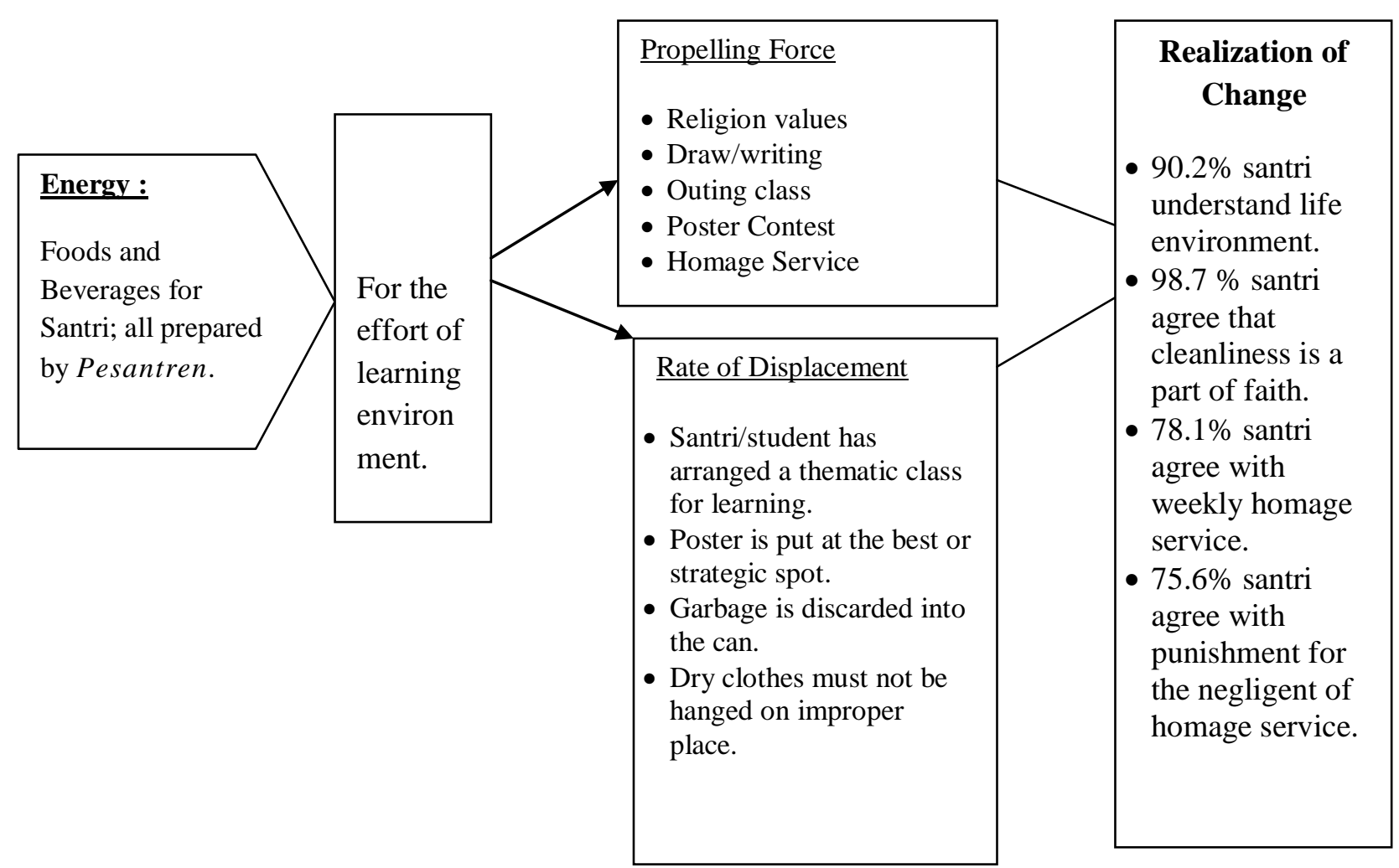

Learning process needs energy, and this energy is contained within foods and beverages that must be prepared by Pesantren. The rate of effort depends on the rate of force given to the effort and also on the rate of displacement (result of learning). All these rates are needed to ensure the success of learning.

\section{Conclusion:-}

Pursuant to data and discussion on the learning of religion values related with life environment in Pesantren, some conclusions are made.

1. Learning process about life environment in Pesantren is performed by internalizing religion values. It aligns with energy conservation law that expects a change from learning result.

2. The learning has brought a change in the direction planned by Pesantren. This direction concerns with environmental issue or with the understanding of students about the issue. Most students (90.2\%) have understood that life environment must be maintained by keeping environment cleaned, discarding garbages into can, refraining from spitting at public space, and helping the people with difficulty. Few students reject this understanding, and the rejecter is dominated by male. However, there is agreement that the review of life environment must be given every day or every week. Only few students reveal a refute to daily or weekly review of life environment. Male students are dominant.

3. Most students $(98.7 \%)$ have agreed with the relationship between cleanliness and faith. Learning process at school/Pesantren is related with the importance of environmental cleanliness. It is done by reciting books about environmental cleanliness, by organizing the outing class or the contests of making poster with contents of environmental cleanliness and learning comfort, and also by conducting homage service around Pesantren. Some students agree these measures despite few male students reject it.

4. Some students (78.1\%) agree with once a week homage service. Other students $(75.6 \%)$ agree to give punishment for the negligent. The suggested punishment is buying cleaning tools or cleaning two rest rooms in two days in a row.

5. Few male students reject life environment concepts and its reviews. This rejection derive from a strong patriarchy culture which frames the way the students think. The condition where students live still influences their behavior. 


\section{References:-}

1. Abdurrahman, Ahmad Taufiq. 2008. Pesantren Modern Dan Pendidikan Multikulturalisme, Artikel.

2. Jahi, Amri. 1993. Komunikasi Massa dan Pembangunan (Jakarta: Yayasan Obor Indonesia.

3. Al-Qardhawi, Yusuf. 2002. Islam Agama Ramah Lingkungan (Ri'ayatul al-Baiatu fi Syari'ati al-Islami) diterj. Abdullah Hakam Syah. Jakarta: Pustaka Al-Kautsar

4. Brannen, Julian. 1997. Memadu Metode Penelitian Kualitatif dan Kuantitatif. Samarinda: Fakultas Tarbiyah IAIN Antasari bekerjasama dengan Pustaka Pelajar

5. Creswell. John W.,2012, Research Design: Pendekatan Kualitatif, Kuantitatif dan Mixed. Yogyakarta: Pustaka Pelajar.

6. Dhofier, Zamakhsyari. 1982. Tradisi Pesantren Studi tentang Pandangan Hidup Jakarta: LP3ES.

7. Haedari, HM Amin. 2004. Masa Depan Pesantren ,Jakarta, IRD Press.

8. Koenig, Samuel. 1957. Mand and Society, The Basic Teaching of Sociology, Cetakan ke dua (New York: Barners \& Noble inc.

9. Moelong, Lexy J. 2011. Metode Penelitian Kualitatif. Bandung : PT. Remaja Rosdakarya.

10. Mastuhu. 1994. Dinamika Sistem Pendidikan Pesantren, Jakarta: INIS.

11. Marzuki, Wahid. (ed.). 1999. Pesantren Masa Depan, Bandung: Pustaka Indah.

12. Nasir, M.R. 2005. Mencari Tipologi Format Pendidikan Ideal: Pondok Pesantren di Tengah Arus Perubahan. Yogyakarta: Pustaka Pelajar.

13. Nasution, S. 2001. Sejarah Pendidikan Indonesia , Jakarta: Bumi Aksara.

14. Padli, M. dan Supriyatno, T. 2007. Sosiologi Pendidikan. Malang: UIN Malang

15. Ranjabar, Jacobus. 2001. Perubahan Sosial Dalam Teori Makro Pendekatan Realitas Sosial (Bandung: Alfabeta, 2001).

16. Shodiq, M. 2011. Pesantren dan Perubahan Sosial, JURNAL FALASIFA. Vol. 2 No. 2 September.

17. Tucker, Mary Evelyn dan John A.Grim. 2003. Agama, Filsafat dan Lingkungan Hidup (terj.). Yogyakarta: Kanisius.

18. Young, Hugh D. \& Freedman, Roger A. 2002. Fisika Universitas (terjemahan), Jakarta Penerbit Erlangga.

19. Ziemek, M. 1986. Pesantren dalam Perubahan Sosial, diterjemahkan oleh Butche B. Soendjojo, Jakarta: P3M 